\title{
Immunoresponse of Coho salmon immunized with a gene expression library from Piscirickettsia salmonis
}

\author{
ALVARO MIQUEL, ILSE MÜLLER, PABLO FERRER, PABLO D. T. VALENZUELA and \\ LUIS O. BURZIO
}

Bios-Chile IGSA, Fundación Ciencia para la Vida and Millennium Institute for Fundamental and Applied Biology, Av. Marathon 1943, Santiago, Chile

\begin{abstract}
We have used the expression library immunization technology to study the protection of Coho salmon Oncorhynchus kisutch to the infection with Piscirickettsia salmonis. Purified DNA from this bacterium was sonicated and the fragments were cloned in the expression vector pCMV-Bios. Two libraries were obtained containing 22,000 and 28,000 colonies and corresponding to approximately 8 and 10 times the genome of the pathogen, respectively. On average, the size of the inserts ranged between 300 and 1,000 bp.

The plasmid DNA isolated from one of these libraries was purified and $20 \mu \mathrm{g}$ were injected intramuscularly into 60 fish followed by a second dose of $10 \mu \mathrm{g}$ applied 40 days later. As control, fish were injected with the same amount of DNA of the vector pCMV-Bios without insert. The titer of IgM anti-P. salmonis of vaccinated fish, evaluated 60 days post-injection, was significantly higher than that of the control group injected with the vector alone. Moreover, this response was specific against $P$. salmonis antigens, since no cross reaction was detected with Renibacterium salmoninarum and Yersinia ruckeri.

The vaccinated and control fish were challenged 60 days after the second dose of DNA with $2.5 \times 10^{7}$ P. salmonis corresponding to 7.5 times the $\mathrm{LD}_{50}$. At 30 days post-challenge, $100 \%$ mortality was obtained with the control fish while $20 \%$ of the vaccinated animals survived. All surviving fish exhibited a lower bacterial load in the kidney than control fish.

The expression library was also tested in Balb/c mice and it was found that the humoral immune response was specific to $P$. salmonis and it was dependent on the amount of DNA injected.
\end{abstract}

Key terms: Piscirickettsia salmonis, genetic vaccine, expression library immunization.

\section{INTRODUCTION}

Piscirickettsia salmonis is the etiologic agent of Salmonid Rickettsial Septicemia (SRS) a disease responsible for extensive mortalities in the Chilean salmon industry. This agent was identified for the first time in 1990 by Fryer (Fryer et al., 1990). The disease occurs mainly in coho salmon (Oncorhynchus kisutch). It was found later that this patogen affects other farmed salmon species (Gaggero, et al., 1995) including salmonids from other countries besides Chile (Brocklebank et al., 1993; Rodger and Drinan, 1993; Olsen et al., 1997).

The pathogen is a Gram-negative obligate intracellular bacterium found in cytoplasmic vacuoles of infected cells. The organism is pleomorphic, predominantly coccoid in shape and ranging 0.5 to $1.0 \mu \mathrm{m}$ in diameter (Fryer et al., 1992). The pathogen was initially isolated from the kidney of a diseased adult coho salmon and successfully cultured in a cell lined derived from Chinook salmon (Oncorhynchus tshawytscha) embryos, known as CHSE214 cells (Fryer et al., 1990).

Presently, the SRS has been partially controlled my means of the use of antibiotics. These are not fully effective and have problems derived from their toxicity and generation of resistance. A more convenient procedure to prevent the infection is the use of vaccines. However, no effective vaccines are currently available against $P$. salmonis. This pathogen grows very slowly, taking 15 to 20 days to develop a full cytopathic effect making it difficult to produce large amounts of cells and to 
separate them from host material, as required for an effective purify bacterin formulation.

Nucleic acid vaccines represent a new approach to the control of infectious agents (Leong et al., 1997). These novel experimental vaccines are both easy to construct and to produce, however the problem still remains of discovering what gene or genes to include in the genetic immunization vector to obtain an efficacious vaccine. This is particularly a problem with pathogens with larger genomes such as bacteria and parasites. One approach that circumvents this problem is the expression library immunization technology developed by Barry and coworkers (Barry et al., 1995). The procedure involves making an expression library from the wole genome of the pathogen in appropriate genetic immunization vectors. This expression library is used in successive immunizations and challenges to eventually strip down the genome into protecting genes (Johnston and Barry, 1997). These concepts were experimentally demonstrated when Barry and collaborators (Barry et al., 1995) showed that immunization of mice with expression libraries of Mycoplasma pulmonis induced protection against a challenge with the pathogen.

Here we report that immunization of Coho salmon with an expression library of $P$. salmonis induced antibody immunity and partial protection to a challenge with the pathogen. We have shown previously that DNA constructs containing $P$. salmonis coding (Tischler et al., 2002) regions elicit immunoresponses in mice (Wilhelm et al., 2002).

\section{MATERIALS AND METHODS}

\section{Bacterial strains}

The bacterial strains used were: $P$. salmonis LF-89 (ATCC VR 1361), Escherichia coli HB101, ATCC 8739, Renibacterium salmoninarum ATCC 33209 and Yersinia ruckeri ATCC 29473.
Growth and purification of $\mathrm{P}$. salmonis

P. salmonis LF-89 was continuously propagated in the Chinook salmon embryo cell line CHSE-214 (CRL 1681 ATCC) (Lannan et al., 1984) using antibiotic-free minimal essential medium (MEM) plus $10 \%$ bovine serum as described elsewhere (Fryer et al., 1990, Jamett et al., 2001). The titer of $P$. salmonis was determined using a plaque formation assay (Lannan et al., 1991). Briefly, serial dilutions of $P$. salmonis were plated on fresh monolayers of CHSE-214 cells in 24-well plates and incubated at $16^{\circ} \mathrm{C}$ for $24 \mathrm{~h}$. After the attachment of $P$. salmonis to the cells, the culture was overlayered with $0.7 \%$ methylcellulose in MEM. Plates were incubated at $16^{\circ} \mathrm{C}$ for 8 days and the number of plaques determined under phase microscopy. P. salmonis was purified using Percoll density gradient centrifugation (Jamett et al., 2001). The final pellet of purified bacterium was suspended in a solution containing $50 \mathrm{mM}$ Tris- $\mathrm{HCl},(\mathrm{pH}$ 7.5), $200 \mathrm{mM} \mathrm{NaCl}$, and the concentration of protein was measured (Smith et al., 1985). To determine the number of bacterial cells/ml, serial dilutions in the Tris-saline solution were counted under phase microscopy in a Neubauer chamber. In this procedure, $1 \mathrm{mg}$ of protein corresponds to approximately $3.8 \times 10^{9} \mathrm{P}$. salmonis cells.

Preparation of genomic DNA from $\mathrm{P}$. salmonis

Genomic P. salmonis DNA was prepared and purified as described (Wilhelm et al., 2003). Briefly, purified P. salmonis cells were first treated with DNAse I (Ogarkova and Balayeva, 1984) following the protocols of Hallberg (1994) and Binder (1995). The cells were suspended in $1 \mathrm{ml}$ of DNAse I buffer $\left(5 \mathrm{mM} \mathrm{MgCl}_{2}, 0.1 \mathrm{mM} \mathrm{CaCl}, 4 \mathrm{mM}\right.$ 2-mercaptoethanol, $0.1 \quad \mathrm{mM} \quad \mathrm{p}$ methylsulphonylfluoride, $200 \mathrm{mM} \mathrm{NaCl}$, $200 \mathrm{mM} \mathrm{KCl}$ and $50 \mathrm{mM}$ Tris $\mathrm{HCl}$ (pH 7.4), treated with $20 \mu \mathrm{l}$ of a $10 \mathrm{mg} / \mathrm{ml}$ DNAse I solution and incubated at $25^{\circ} \mathrm{C}$ for 60 minutes. Then, the cells were pelleted by centrifugation, resuspended in $0.5 \mathrm{ml}$ of 
PBS with $0.1 \mathrm{ml}$ of $0.1 \mathrm{M}$ EDTA, pelleted again by centrifugation and resuspended in cell lysis buffer $(0.75 \mathrm{M}$ sacarose, $400 \mathrm{mM}$ $\mathrm{NaCl}, 20 \mathrm{mM}$ EDTA, $0.2 \%$ SDS, $1 \mathrm{mg}$ of proteinase $\mathrm{K}$ and $50 \mathrm{mM}$ Tris $\mathrm{HCl}(\mathrm{pH}$ 9.0)). The suspension was incubated at $58^{\circ} \mathrm{C}$ for 1 hour with gently stirring. The resulting DNA solution was extracted once with phenol saturated with Tris- $\mathrm{HCl}(\mathrm{pH}$ 8.0) and twice with chloroform: isoamyl alcohol (24:1) and precipated for $30 \mathrm{~min}$ with 0.4 volumes of $5 \mathrm{M}$ ammonium ace tate and 2.5 volumes of absolute ethanol at $-20^{\circ} \mathrm{C}$. The pellet was washed with cold $70 \%$ ethanol and dissolved in $1 \mathrm{mM}$ EDTA, $10 \mathrm{mM}$ Tris $\mathrm{HCl}$ (pH 8.0).

Preparation of $\mathrm{P}$. salmonis expression libraries

Purified $P$. salmonis DNA was sonicated at $4^{\circ} \mathrm{C}$ in aliquots of $15 \mathrm{mg}$ each to an approximate size of 1,000 to 2,000 base pairs, as determined by agarose gel electrophoresis. Subsequently, the extremes of the DNA fragments were repaired using DNA polymerase I Klenow fragment and ligated overnight at $14-16^{\circ} \mathrm{C}$ to blunt-ended linearized plasmid pCMVBios (Figure 1) in a 10:1 fragment: vector molar relationship using T4 DNA ligase at

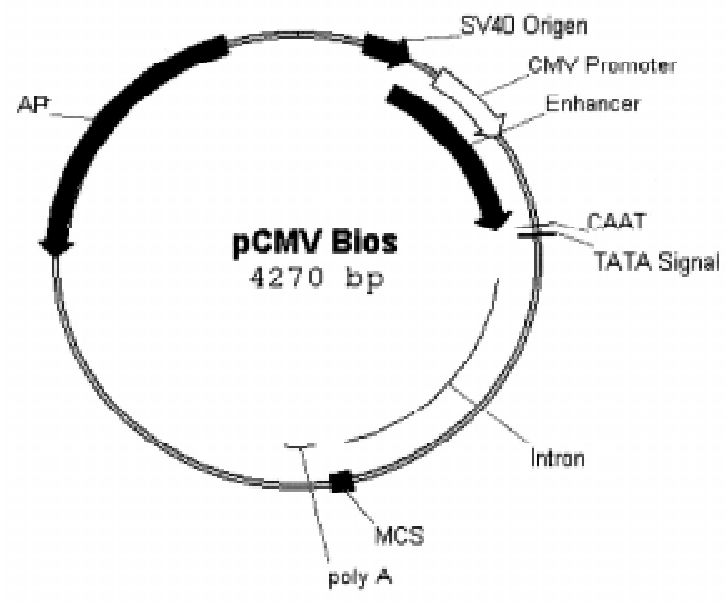

Figure 1. Schematic representation of the animal expression vector pCMV-Bios.

The vector contains the amp resistance gene as selection marker, the CMV promoter-enhancer system and a polyadenylation signal downstream the multiple cloning site (MCS). a concentration of $20 \mathrm{U} / \mu \mathrm{l}$. The ligation mixture was used to transform competent E. coli HB 101 cells. For immunization, plasmid DNA pooled from 4 preparations from a total of 22,000 colonies was liofilized and suspended in $0.9 \%$ of $\mathrm{NaCl}$ to a final DNA concentration of $0.1 \mathrm{mg} / \mathrm{ml}$.

\section{Immunization of Balb/c mice}

Balb/c mice 6-8 weeks old were immunized by injection in the anterior tibia muscle with 5,20 and $50 \mu \mathrm{g}$ respectively of vector or library DNA dissolved in $0.9 \% \mathrm{NaCl}$, $25 \%$ sacarose and $50 \mathrm{ppm}$ of tricaine metasulphonate.

\section{Immunization of salmon}

Coho salmon of approximately $20 \mathrm{~g}$ were treated with $30 \mathrm{ppm}$ of tricaine metanesulphonate for $10 \mathrm{~min}$ and injected with $20 \mu \mathrm{g}$ of vector or library DNA in 200 $\mu l$ of sterile $0.9 \% \mathrm{NaCl}, 25 \%$ sacarose and $50 \mathrm{ppm}$ of tricaine metasulphonate split in four sites $(50 \mu \mathrm{leach})$ at the dorsal anterior muscle. After 41 days, fish were immunized with an additional aliquot of $10 \mu \mathrm{g}$ of DNA dissolved in $100 \mu \mathrm{l}$ of the above solution, using the above procedure. All fish were maintained at an average temperature of $12^{\circ} \mathrm{C}$, in alternating dark and light periods of $12 \mathrm{hr}$ each.

The presence of $P$. salmonis-specific IgM antibodies in the serum of salmon immunized with DNA was determined by ELISA. Ninety six well microtiter plates were coated with a $3 \mu \mathrm{g} / \mathrm{ml}$ solution of Aulacomya ater bioadhesive (Burzio et al., 1996), incubated $30 \mathrm{~min}$ at room temperature, washed and dried for $30 \mathrm{~min}$ at $37^{\circ} \mathrm{C}$. The wells of the coated plate were activated with $100 \mu \mathrm{l}$ of a suspension containing $10 \mu \mathrm{g} / \mathrm{ml}$ of $P$. salmonis bacterial extract in $\mathrm{PBS}(\mathrm{pH} 7.2)$ and incubated for $60 \mathrm{~min}$ at $37^{\circ} \mathrm{C}$. Subsequently, the plates were incubated with a solution of $0.5 \%$ Tween 20 and $5 \%$ non-fat milk for $60 \mathrm{~min}$ at $37^{\circ} \mathrm{C}$ and dried for $60 \mathrm{~min}$ at $37^{\circ} \mathrm{C}$.

The sera to be analyzed were serially diluted, incubated in each well for $3 \mathrm{hr}$ at 
room temperature. Then, the dilutions were discarded and the wells were washed 3 times with $0.02 \%$ Tween 20 in PBS. Subsequently, $100 \mu \mathrm{l}$ of a solution of anti salmon $\operatorname{IgM}$ monoclonal antibody was added to each well and incubated $2 \mathrm{hr}$ at room temperature. After washing 3 times with $0.02 \%$ Tween 20 in PBS, $100 \mu$ l of a peroxidase-conjugated anti mice $\mathrm{IgG}$ monoclonal antibody were added to each well, incubated $30 \mathrm{~min}$ at room temperature in the dark, developed with TMB and hydrogen peroxide and read at $450 \mathrm{~nm}$.

\section{Determination of the LD50}

A total of 56 coho salmon of approximately $150 \mathrm{~g}$ each, were divided in 7 groups of 8 salmon each. Each group was inoculated by intraperitoneal injection with $200 \mu$ of a suspension, containing increasing amounts of Piscirickettsia salmonis LF-89 in PBS containing $200 \mathrm{mM} \mathrm{NaCl}$. The fate of the fish was followed for 8 weeks and the accumulative mortality was recorded for each group of fish treated with the different dose of pathogen.

\section{Challenge of fish immunized with DNA formulations}

Coho salmon immunized with the DNA expression library as well as with pCMVBios vector alone (control) were anesthetized and challenge by intraperitoneal injection of $200 \mu \mathrm{l}$ of a suspension of PBS containing $200 \mathrm{mM} \mathrm{NaCl}$ containing $2.5 \times 10^{7} P$. salmonis ( 7.5 times the LD50). The challenge experiment was carried out for 30 days post-challenge and the mortality was verified daily. The presence of $P$. salmonis in dead fish was measured by immunofluorescence in kidney and brain tissues. The level of anti P. salmonis IgM was measured in selected animals by ELISA.

\section{ELISA and Immunofluorescence}

Polystyrene microtiter plates (PolySorp) were coated with the adhesive polyphenolic protein purified from the mussel Aulacomya ater (Burzio et al., 1996). Briefly, $100 \mu l$ of a $3 \mu \mathrm{g} \mathrm{ml}^{-1}$ solution of the adhesive in $0.1 \%$ acetic acid was applied to each well and incubated fro $30 \mathrm{~min}$ at room temperature. The acidic solution was discarded and the plate was air dried at $37^{\circ} \mathrm{C}$ for $1 \mathrm{~h}$. To bind a given antigen to the coated plate, $100 \mu \mathrm{l}$ of antigen solution in PBS containing between 0.75 and $12 \mu \mathrm{g} \mathrm{ml}^{-1}$ of protein was applied to each well and incubated for $2 \mathrm{~h}$ at $37^{\circ} \mathrm{C}$. After discarding the solution, the plate was washed once with distilled water and then blocked with a solution containing $2 \%$ casein and $2 \%$ sucrose in PBS for $2 \mathrm{~h}$ at room temperature. The blocking solution was discarded, and the plate was air dried for $2 \mathrm{~h}$ at $37^{\circ} \mathrm{C}$ and stored at $4^{\circ} \mathrm{C}$ in a sealed plastic envelope with desiccant. Further ELISA procedures and color development was carried out as described before (Aguayo et al., 2002).

To prepare the tissue extract, about 200 mg of salmon kidney was transferred to a plastic bag together with 2 volumes (w/v) of a solution containing $0.3 \mathrm{M}$ sucrose, $0.15 \mathrm{M}$ $\mathrm{NaCl}, 5 \mathrm{mM} \mathrm{MgCl}, 1 \mathrm{mM} \mathrm{CaCl}$ and $10 \mathrm{mM}$ sodium phosphate buffer ( $\mathrm{pH} 7.5)$. The bag was sealed to avoid contamination and the kidney was macerated with a spatula. The macerate was transferred to a sterile Eppendorf tube and centrifuged at $2000 \times \mathrm{g}$ for $5 \mathrm{~min}$.

To detect the presence of $P$. salmonis in fish tissues, samples of kidney and brain were subjected to indirect immunofluorescence using monoclonal antibody $7 \mathrm{G} 4$ as described before (Jamett et al., 2001).

\section{RESULTS AND DISCUSSION}

Culture of $\mathrm{P}$. salmonis

$P$. salmonis is a strict intracellular bacteria which grows only in cultured cells such as salmon CHSE-214 cells. Figure 2 shows an electron microscopy picture of the CHSE-214 cells infected with $P$. salmonis. This picture depicts some of the characteristics of the intracellular growth of the bacteria such as their localization inside vacuoles of the host cells, the 


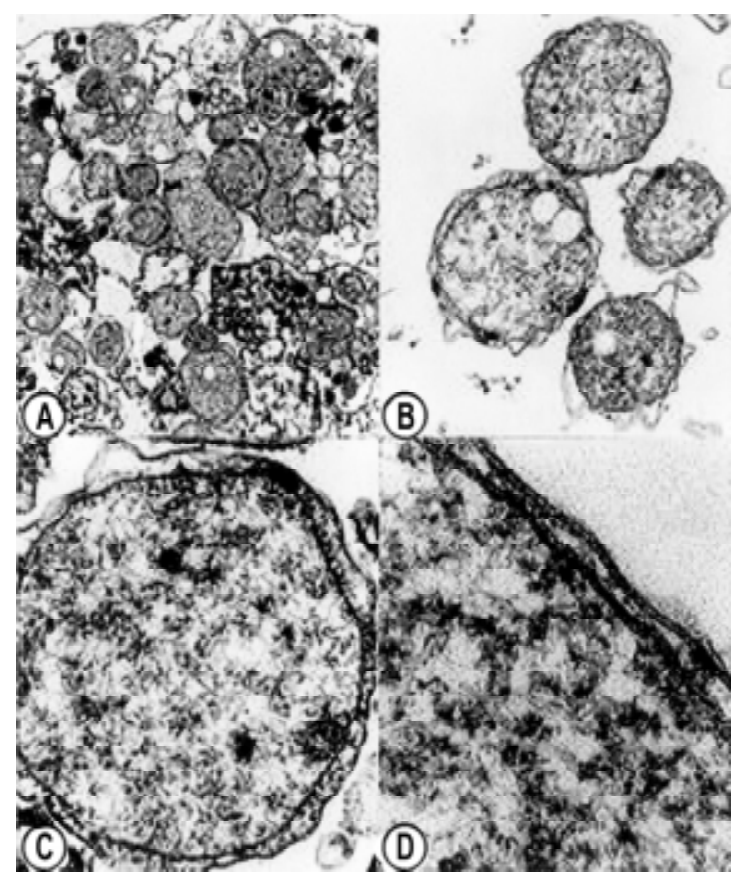

Figure 2. Ultrastructural analysis of CHSE-214 cells infected with P. salmonis.

A: CHSE-214 cell infected with several $P$. salmonis at 10,000 $\mathrm{x}$ magnification. B: cytoplasmic vacuoles with four $P$. salmonis cells in its interior at 15,000 x magnification. C: $P$. salmonis cell at $60,000 \mathrm{x}$ magnification. D: External and internal membrane at 205,000 x magnification.

presence of their double membrane with an ondulant external membrane and their appearance as electron-dense bodies in the bacterial cytoplasm. Cultured CHSE-214 cells infected with $P$. salmonis are considered ready for harvesting when nearly $100 \%$ of the cells showed cytopathic effects. At this stage the percentage of viable $P$. salmonis cells is always higher than $95 \%$, the number of CHSE-214 cells is about 100,000 cells $/ \mathrm{cm}^{2}$ and the number of $P$. salmonis is about $1 \times 10^{3}$ bacteria/cell.

\section{Purification of $\mathrm{P}$. salmonis}

Due to the large difference in genome size between bacteria and salmon, nuclei contamination of bacterial cells is a significant problem in obtaining highly purified bacterial DNA devoid of salmon DNA. One can calculate that one nuclei of a salmon cell contains 6,000 more DNA that one $P$. salmonis cell. Our first approach was the use of density gradient purification in sacarose. However, this procedure yielded bacteria contaminated with salmon DNA detected by amplification of the salmon growth hormone gene by PCR (results not shown). Because of this, we decided to use DNAse I which could degrade salmon nuclear DNA and leave intact the pathogen DNA protected by the bacterial double membrane. This procedure was previously used by Ogarkova and Balayeva to obtain Rickettsia prowazekii DNA free of host chicken DNA (Ogarkova and Balayeva, 1984). Also, Binder (1995) used DNAse I to purify mitochondrial DNA and RNA from contaminating chromosomal DNA.

DNAse I is very efficient, in the presence of $\mathrm{Mg}^{++}$and traces of $\mathrm{Ca}^{++}$, in degrading single and double stranded DNA. Once completed the digestion, the enzyme can be completely inhibited by a mixture of $10 \mathrm{mM}$ EDTA and $0.2 \mathrm{mM}$ EGTA. The purity and integrity of the high MW bacterial DNA obtained by this procedure was demonstrated by a combination of gel electrophoresis to verify its size, amplification of $P$. salmonis 16S rRNA gene and by amplification (or its absence) of the salmon growth hormone gene (results not shown).

\section{Construction of $\mathrm{P}$. salmonis expression} libraries

The $P$. salmonis genomic library was obtained employing a shotgun cloning procedure (Hengen, P., 1997) using DNA fragments obtained by sonication (Figure 3). Two libraries were obtained, each from $15 \mu \mathrm{g}$ of $P$. salmonis DNA, resulting in 22,242 and 28,365 colonies respectively. Considering this number of colonies and assuming DNA fragments of 1,000 base pairs and a bacterial genome size of $1 \times 10^{6}$ it is possible to calculate that they are equivalent to 22.2 and 28.4 bacterial genomes. Correcting for orientation in the vector $(1 / 2)$ and reading frame (1/3), these libraries represented approximately 3.7 and 4.7 bacterial genomes, respectively.

The presence of DNA inserts in the plasmids from the DNA library was demonstrated by double digestion of 


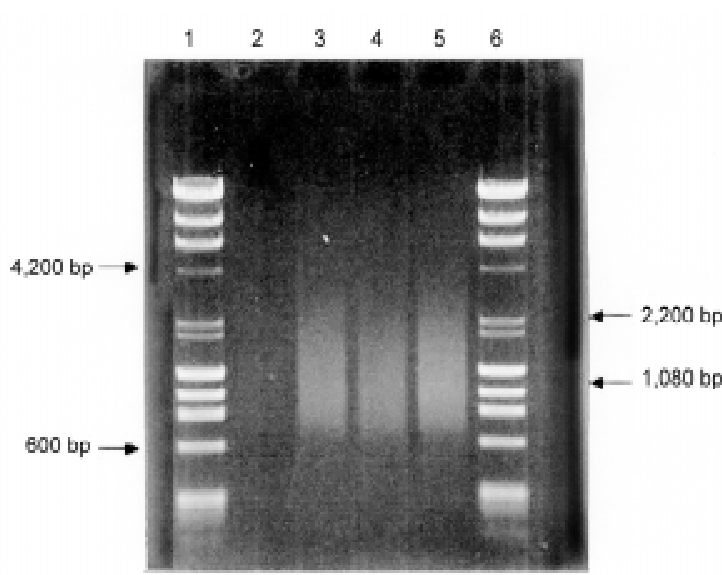

Figure 3. Fragmentation of $P$. salmonis DNA by sonication. Lanes 1 and 6: lambda HindIII and $\varnothing$ X174 HaeIII DNA MW standards; lanes 2 to 5: aliquots of sonicated $P$. salmonis DNA.

plasmid DNA from 12 randomly selected transformant colonies with the endonucleases EcoRI and HindIII. The results of Figure 4 show that all of them have inserts. Plasmid DNA from colonies 2, 4, 5, 9, 10, 11 and 12 gave 2 fragments, one of 900 to 1,100 base pairs and another of 450 to 600 base pairs. DNA from colonies 3 and 6 yielded only one fragment of about
550 to 600 base pairs and colony 8 yielded 2 fragments of approximately 200 to 300 base pairs. The presence of multiple fragments is probably the result of internal EcoRI or HindIII sites in the cloned DNA. The analysis was extended to DNA from 30 bacterial colonies with very similar results. These experiments indicate that about $80 \%$ of the plasmid library contains DNA inserts of the expected size.

Immunization of Coho salmon with the expression library and challenge with $\mathrm{P}$. salmonis.

Fish were vaccinated as described in Materials and Methods. Sixty days after vaccination fish were challenged with one dose of $2.5 \times 10^{7} P$. salmonis which corresponded to 7.5 times the determined LD50. One week after the challenge, the fish showed a slower activity quite different to non-challenged animals. About day 10 after challenge fish started to die. After 20 days, $100 \%$ of vector vaccinated control fish and $80 \%$ of the DNA vaccinated were dead. This percentage was unchanged in the following weeks (Figure 5). The vaccinated

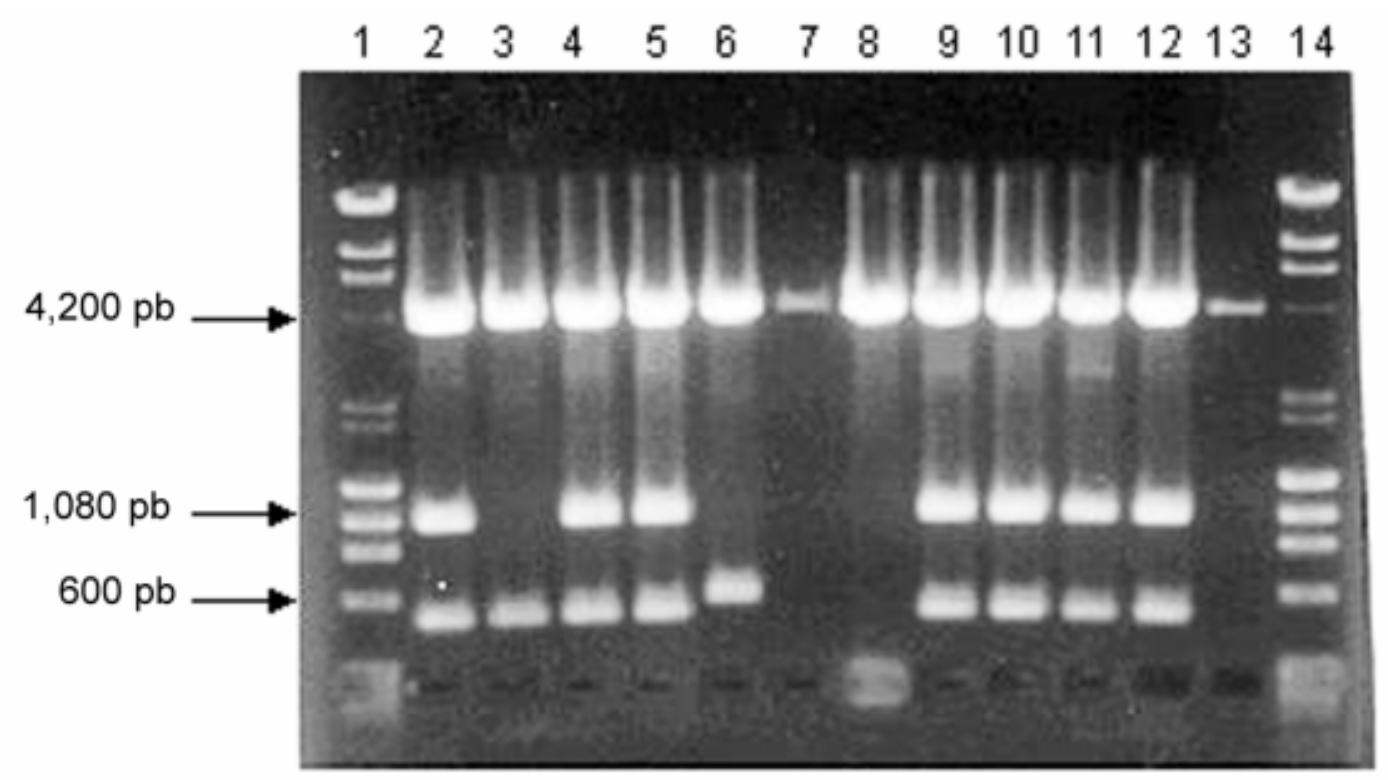

Figure 4. Liberation of inserted DNA fragments from plasmids of the DNA library by digestion with the endonucleases HindIII and EcoRI.

Lanes 1 and 14: lambda HindIII and $\varnothing$ X174 HaeIII DNA MW standards; lanes 2 to 13: plamid DNA from 11 random DNA library E. coli colonies. 


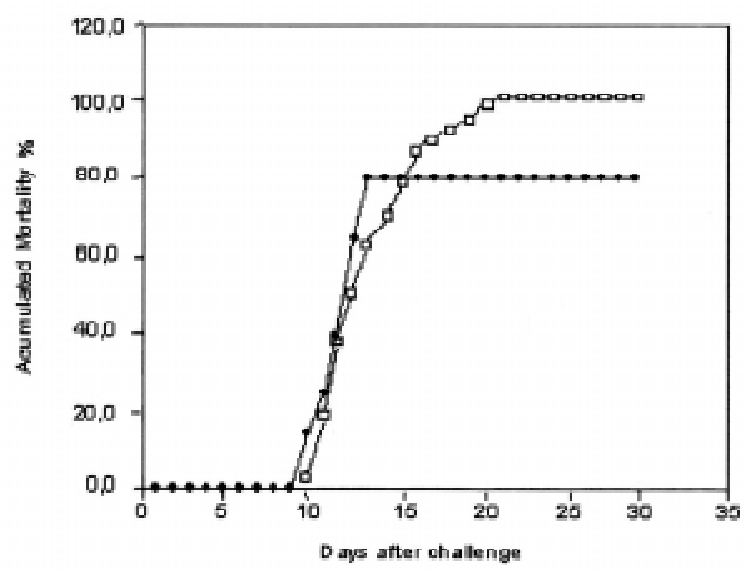

Figure 5. Accumulated mortality of vaccinated and nonvaccinated Coho salmon after a challenge with $P$. salmonis. $\square$ : control fish; : vaccinated fish. fish that survived recovered their appetite and vitality with a behavior identical to the unchallenged control fish. All dead fish were analyzed macroscopically and found to show all the signs described for SRS. These were anemia as evidenced by white gills; high amounts of mucous liquid in the abdominal cavity, and evident hemolisis and destruction of organs such as kidneys, spleen, liver, brain and heart. Direct immunofluorescence with anti-P. salmonis monoclonal antibody 7G4 (Jamett et al., 2001) revealed the presence of a very high amount of bacteria in the kidney. The kidney is the target organ to detect infectious agents in salmonids due to its

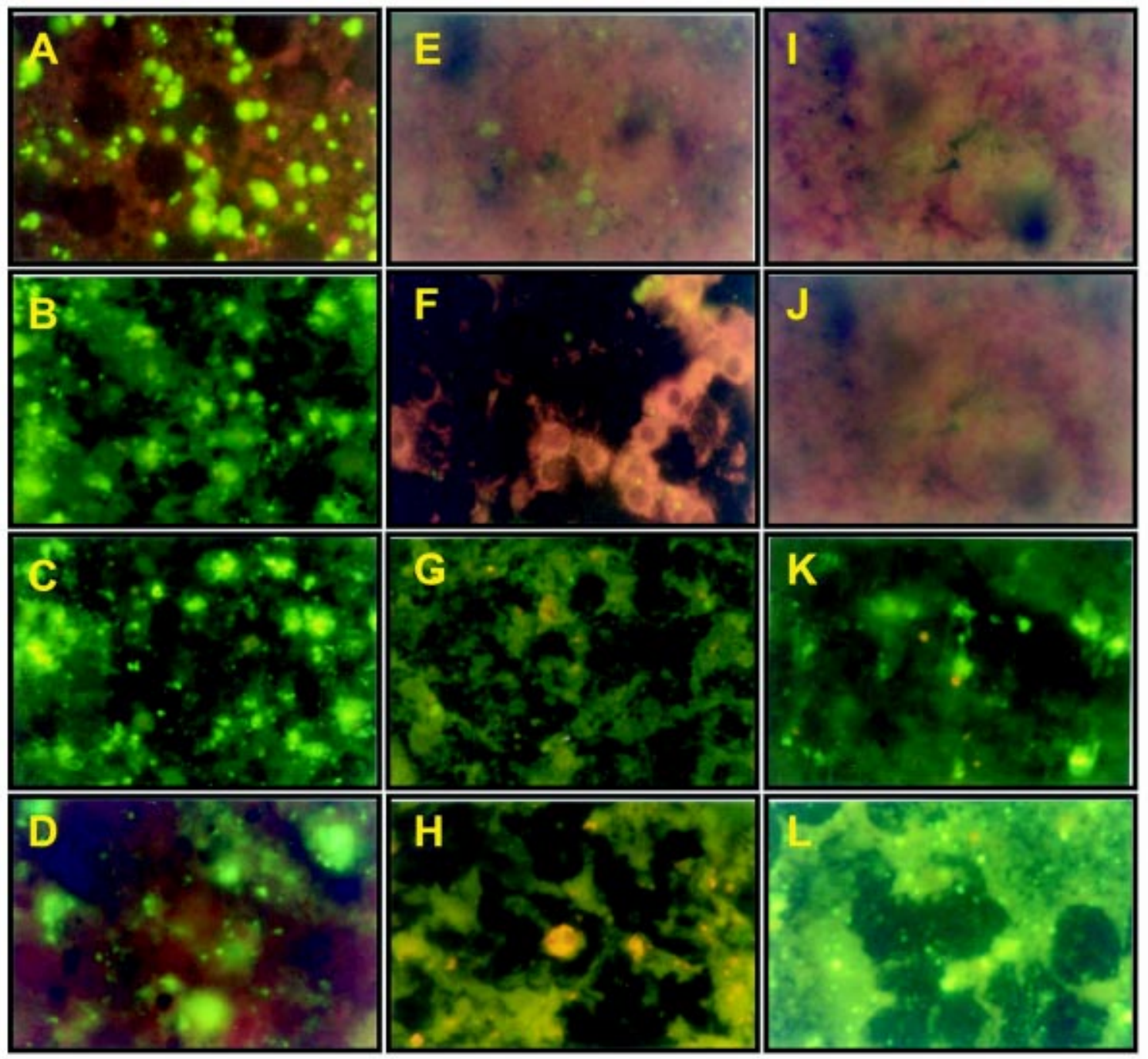

Figure 6. Detection of $P$. salmonis in salmon kidney tissues by direct immunofluorescence.

Detection was carried out using monoclonal antibody $7 \mathrm{GH}$ conjugated to FITC. A, B, C and D: kidney tissue of dead fish after challenge; E, F, G and H: kidney tissue of non-vaccinated non-challenged fish; I, J, K and L: kidney tissue of vaccinated fish that survived the challenge. 
hemaetopoyetic function in fish. The large amount of bacteria is in agreement with the high capacity of infection and replication of this bacteria in this host. This result is shown in Figure 6 where four representative fish are analyzed by immunofluorescence.

The vaccinated fish that survived the challenge were sacrificed and analyzed. These fish did not show the anatomopathologic signs present in nonsurviving fish. All organs were found healthy and normal. In addition, analysis by immunofluorescence showed significantly less $P$. salmonis compared to the amount found in dead fish. It appears therefore that there is a direct correlation between the organ damage and the amount of bacteria detected. We believe this lower damage and lower bacterial load are a consequence of the immunization with the library DNA. However, it is also possible that the higher resistance of these fish may be due to intrinsic genetic factors of a subgroup of fish. The somewhat low percentage of protection may be due to several reasons. One could the very high amount of challenge bacteria used in this first attempt $\left(2.5 \times 10^{7}\right)$ which is significantly higher that the amount involved in a natural infection. Another explanation could be the very high complexity of the library used which would imply a very low concentration of the hypothetical effective genes.

Evaluation of immunoresponse of vaccinated Coho salmon

The humoral response of vaccinated and non vaccinated control fish was evaluated by ELISA after the first and second dosis of vaccine. The results are shown in Figure 7. At 40 days, fish vaccinated with $20 \mu \mathrm{g}$ of library DNA showed a level of $P$. salmonis IgM higher than control fish. At 100 days after vaccination, which included a second

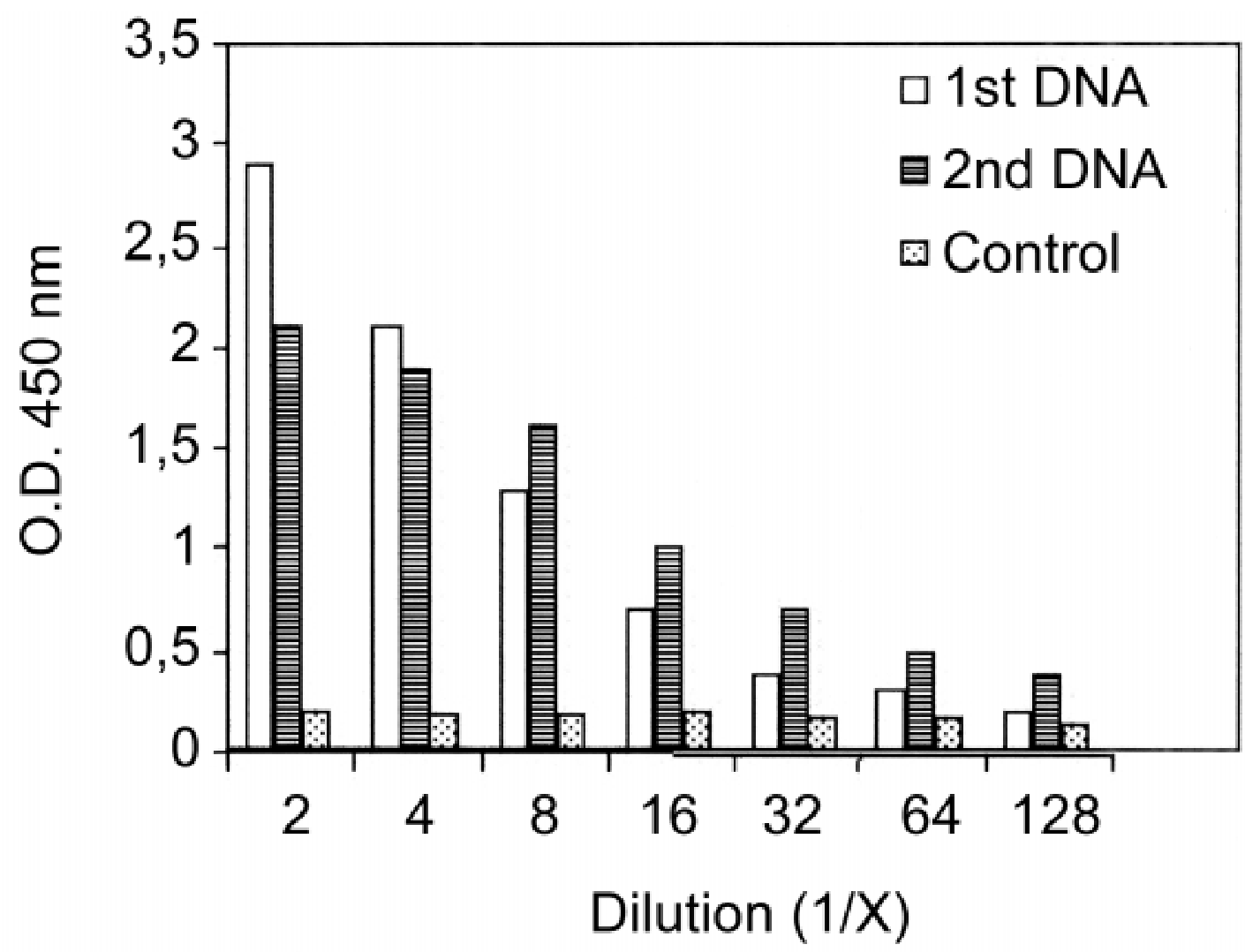

Figure 7. Detection of anti-P. salmonis IgM in salmon vaccinated with DNA from the library.

$1^{\text {st }}$ DNA: response at 40 days after the first immunization with $20 \mu \mathrm{g}$ of DNA. $2^{\text {nd }}$ DNA: response at 60 days after a second immunization with $10 \mu \mathrm{g}$ of DNA. 


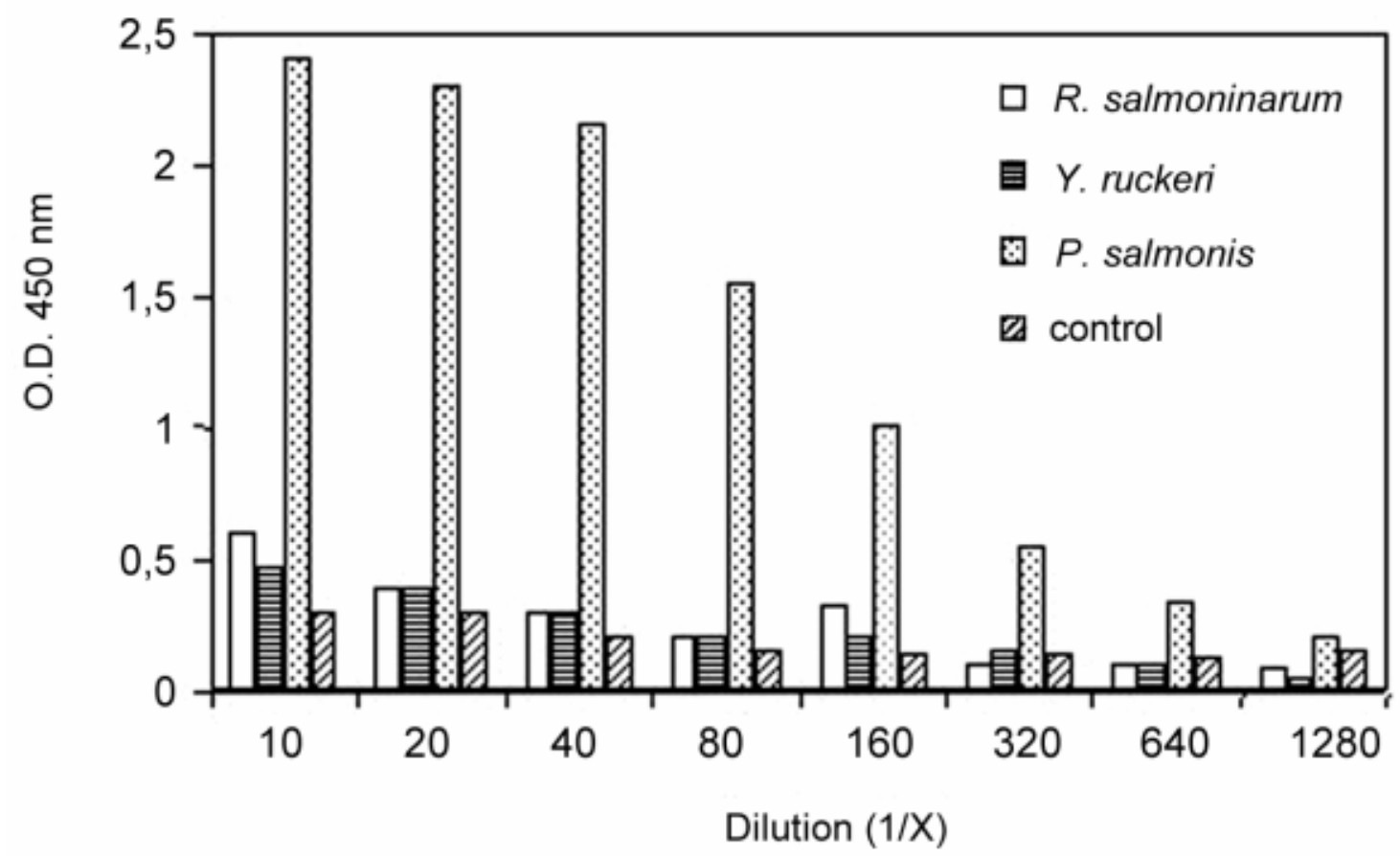

Figure 8. Specificity of the humoral response of salmon vaccinated with the P. salmonis DNA library.

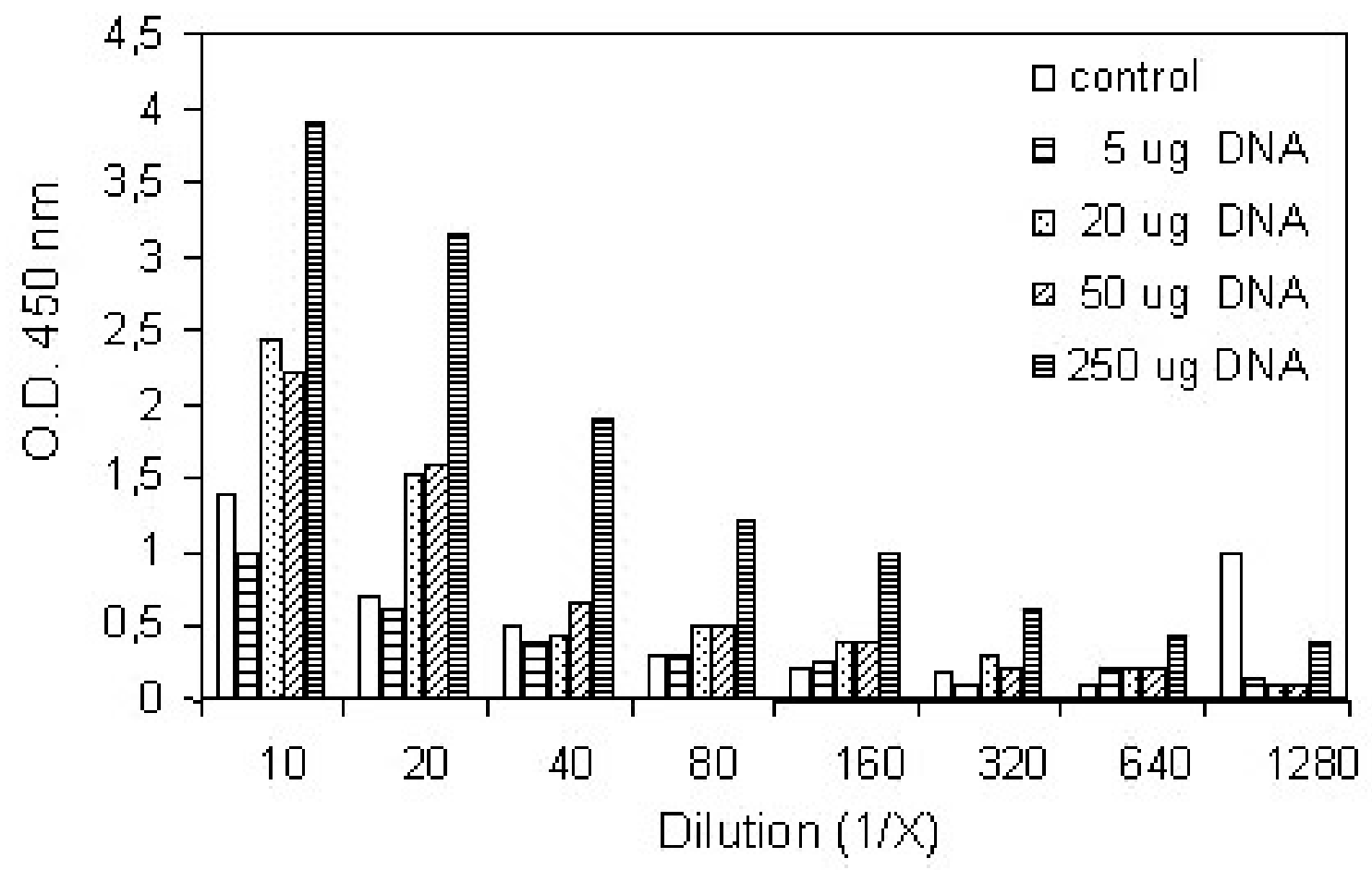

Figure 9. Dose-dependent anti $P$. salmonis humoral response of mice vaccinated with the P. salmonis DNA library. 
dosis of $10 \mu \mathrm{g}$ of library DNA at day 60 , the level of IgM did not increase significantly. This humoral response appears specific for $P$. salmonis since sera of fish vaccinated with the library did not react significantly with antigens of Renibacterium salmoninarum or Yersinia ruckeri, which are common pathogens of salmonids (Figure 8).

\section{Evaluation of immunoresponse in mice}

We were also interested in determining if the library DNA was able to induce a humoral response in mice. With this objective Balb c mice were injected with 5 , 20,50 and $250 \mu \mathrm{g}$ of library DNA in one dosis. The level of antibodies was measured by ELISA using purified $P$. salmonis as antigen. The results are shown in Figure 9. They show that the response is dosedependent with a very clear effect at the $250 \mu \mathrm{g}$ dosis. This is quite similar to reports by others (Davis et al., 1993). This humoral response detected in immunized mice is specific for $P$. salmonis. No response was detected in ELISA assays using Renibacterium salmoninarum or Yersinia ruckeri as antigens (Figure 10).

\section{CONCLUSIONS}

The results described in this paper indicate that an experimental vaccine composed of a wide collection of expressable $P$. salmonis coding regions is able to produce a measurable level of protection in salmon to a challenge with the pathogen. This protection has been demonstrated by a decreased level of mortality, decreased bacterial load and the presence of specific anti $P$. salmonis IgM showed by the vaccinated fish.

The experimental approach described here can be continued further. It may now be possible to deconvolute this genomic expression library by successive immunizations and challenge with pools

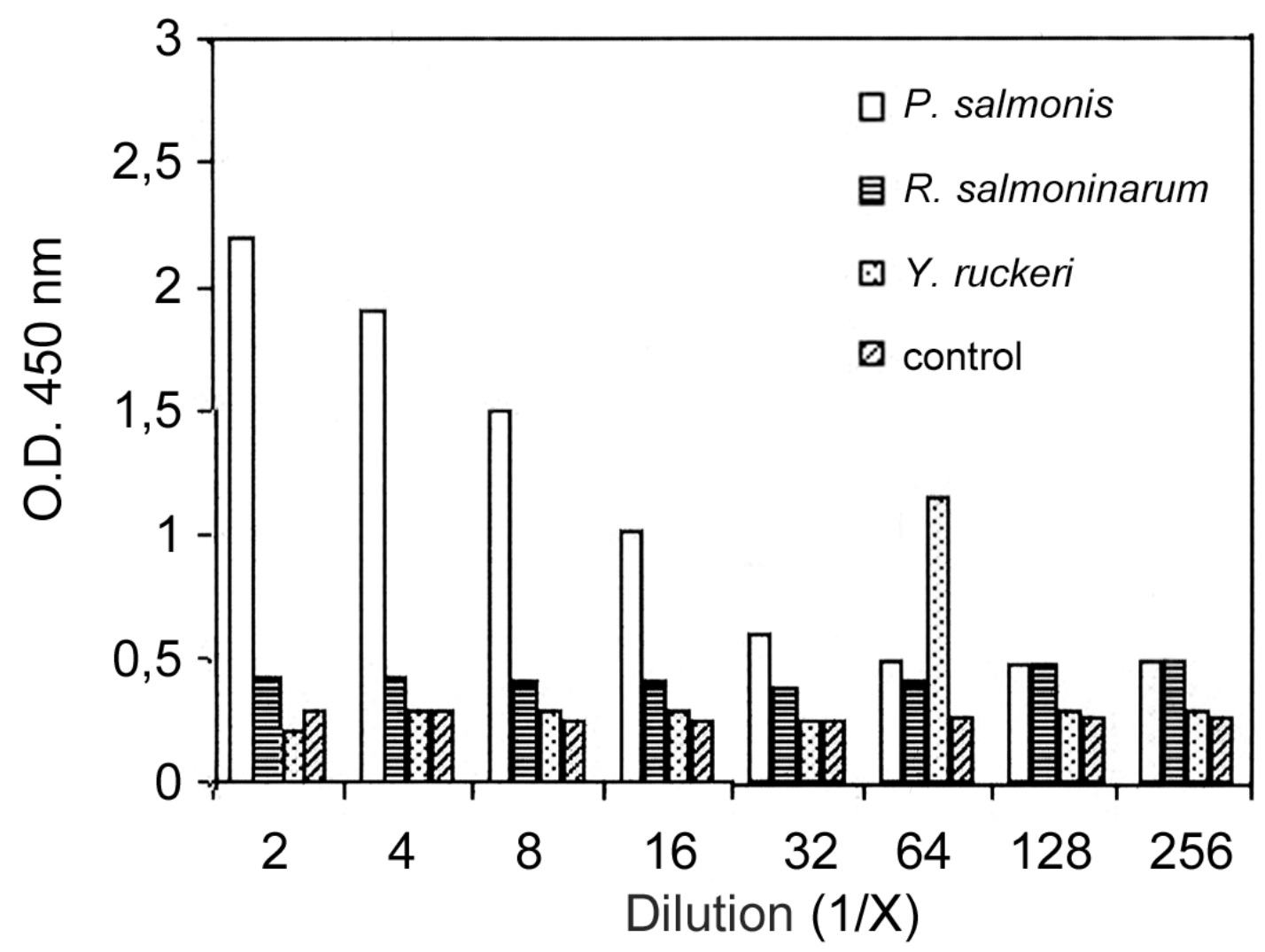

Figure 10. Specificity of the anti P. salmonis humoral response of mice vaccinated with the P. salmonis DNA library. 
of decreasing complexity until the DNA clones responsible for protection can be identified and isolated.

\section{ACKNOWLEDGEMENTS}

We thank María A. Medina-Selby for assistance in the preparation of the DNA libraries and to Bernardita Méndez, Arturo Yudelevich and Mario Rosemblatt for their helpful comments on this manuscript.

\section{REFERENCES}

AGUAYO J, MIQUEL A, ARANKI N, JAMETT A, VALENZUELA PDT. AND BURZIO LO (2002) Detection of Piscirickettsia salmonis in fish tissues by an enzyme-linked immunoabsorbent assay using specific monoclonal antibodies. Dis Aquat Org 49, 33-38

BARRY MA, LAI WC AND JOHNSTON SA (1995) Protection against mycoplasma infection using expression-library immunization. Nature 377, 632635

BINDER S (1965) Mitochondrial nucleic acid purification and analysis. Methods in Molecular Biology 20, 1-6

BROCKLEBANK JR, EVELYN TP, SPEARE DJ AND ARMSTRONG RD (1993) Rickettsial septicemia in farmed Atlantic and Chinook salmon in British Columbia: clinical presentation and experimental transmission. Can Vet J 34, 745-748

BURZIO VA, SILVA T, PARDO J, BURZIO LO (1996) Mussel adhesive enhances the immobilization of human chorionic gonadotrophin to a solid support. Anal Biochem 241: 190-194

DAVIS H, MICHEL M AND WHALEN R (1993) DNAbased immunization induces continuous secretion of hepatitis B surface antigen and high levels of circulating antibody. Hum Mol Genet 2: 1847-1851

FRYER J, LANNAN C, GARCÉS L, LARENAS J AND SMITH P (1990) Isolation of a rickettsiales-like organism from diseased coho salmon (Oncorhynchus kisutch) in Chile. Fish Pathol 25, 107-114

FRYER J, LANNAN C, GIOVANNONI S AND WOOD N. (1992) Piscirickettsia salmonis gen nov., sp. Nov., the causative agent of an epizootic disease in salmonid fishes. Int. J Syst Bacteriol 42, 120-126

GAGGERO A, CASTRO H, SANDINO AM (1995) First isolation of Piscirikettsia salmonis from coho salmon (Oncorhynchus kisutch) and rainbow trout (Oncorhynchus mykiss) during the freshwater stage of their life cycle. J Fish Dis 18, 277-279
HALLBERG E (1994) Preparation of nuclei and nuclear envelopes: Identification of an integral membrane protein unique to the nuclear envelope. Cell Biology: A laboratory handbook, vol. I, pag. 613-618. J. E. Celis Ed. Academic Press Inc., San Diego, California

HENGEN P (1997) Shearing DNA for genomic library construction. Trends Biochem Sci 7: 273-274

JAMETT A, AGUAYO J, MIQUEL A, MÜLLER I, ARRIAGADA R, BECKER MI, VALENZUELA PDT AND BURZIO LO (2001) Characterization of monoclonal antibodies against Piscirickettsia salmonis. J Fish Dis 24, 205-215

JOHNSTON SA AND BARRY MA (1997) Genetic to genomic vaccination. Vaccine 15, 808-809

LANNAN C, EWING S AND FRYER J (1991) A fluorescent antibody test for the detection of the Rickettsia causing disease in Chilean salmonids. J. Aquat. Animal Health 3, 229-234

LANNAN CN, WINTON JR, FRYER JL (1984) Fish cell lines: establishment and characterization of nine cell lines from salmonids. In Vitro 20: 671-676

LEONG JC, ANDERSON E, BOOTLAND LM, CHIOU PW, JOHNSON M, KIM C, MOURICH D AND TROBIDGE G (1997) Fish vaccine antigens produced or delivered by recombinant DNA technologies. Gudding R, Lillehaug A, Midtlyng, P.J., Brown, F. (Eds): Fish Vaccinology Dev Biol Stand Basel, Karger 90: 267-277

OGARKOVA OA AND BALAYEVA NM (1984) The use of Dnase for preparation of host tissue DNA-free rickettsial suspensions. Acta Virol 28, 73-74

OLSEN AB, MELBY HP, SPELLBERG L, EVENSSEN O AND HASTEIN T (1997) Piscirickettsia salmonis infection in Atlantic salmon Salmo solar in Norway, epidemiological, pathological and microbiological findings. Dis Aquat Org 31, 35-48

RODGER HD AND DRINAN EM (1993) Observation of a rickettsia-like organism in Atlantic salmon Salmo salar in Ireland. J Fish Dis 16, 361-369

SMITH PK, KROHN RI, HERMANSON GT, MALLIA AK AND GARTNER FH, PROVENZANO MD, FUJIMOTO EK, GOEKE NM, OLSON BJ, KLENK DC (1985) Measurement of protein using bicinchoninic acid. Anal Biochem 150: 76-85

TISCHLER N, LISBONA F, MÜLLER I, MARTÍNEZ R, FERNÁNDEZ J, ROSEMBLATT M AND VALENZUELA P (2002) Sequence and expression of genes of Hantavirus Andes. Biol Res 35: R-104

WILHELM V, ENGEL E, ERAZO E, HERNANDEZ C, HUARACAN B, JAMETT A, MORALES C, SOZA C, BURZIO LO, ROSEMBLATT M AND VALENZUELA PDT (2002) Studies on the immunogenic potential of Piscirickettsia salmonis proteins expressed in vivo in mouse. Biol Res 35: 104

WILHELM V, VILLEGAS J, MIQUEL A, ENGEL E, BERNALES S, VALENZUELA PDT AND BURZIO LO (2003). The complete sequence of the mitochondrial genome of the Chinook salmon Oncorhynchus tshawytscha. Biol Res 36: 223-231 